\title{
Mechanical grading in PGI Tropea red onion post harvest operations
}

\author{
Bruno Bernardi, Giuseppe Zimbalatti, Andrea Rosario Proto, Souraya Benalia, \\ Antonio Fazari, Paola Callea \\ University Mediterranea of Reggio Calabria, Department of AGRARIA, Reggio Calabria, Italy
}

\begin{abstract}
The growing interest expressed by consumers toward food products quality as well as toward their linkage to the territory, has led producers to fit to the continuous rising demand for "typical products", and to look for new and more efficient production and marketing strategies. An emblematic case is represented by Tropea red onion that, as a typical product, plays an important role in economical and rural development of the territory to which it is linked. The organoleptic features offered by "Tropea Red Onion", PGI certified (Calabria), have to be associated as well to the quality of services that accompanies its processing. Technology application in post-harvest operations, has certainly contributed to make faster and less tiring all processing tasks. The main problem related to the mechanization of Tropea red onion post-harvest operations lies in the removal of the various layers of the external tunic, making it impossible for optical or electronic grader to achieve this task in a satisfactory way since the sensors are not able yet to separate the "bulb" from its involucre. In this context, the current study aims to assess the productivity of three different machines used for round Tropea red onion grading, and determine their work efficiency. The carried out analysis highlighted the ability of the studied machines to ensure a high work capacity, while maintaining a high level of precision during calibration process. Such precision allows to decrease laborer employment and increase processing chain speed, rising as well the annual use of the machines, allowing consequently processing cost savings. For a more profitable employment of such graders, it is, however, necessary from one hand, to properly form the technicians responsible of processing plants management, and from the other hand, to be able to take advantage of a technical assistance network, able to serve users in a short time.
\end{abstract}

\footnotetext{
Correspondence: Bruno Bernardi, University Mediterranea of Reggio Calabria, Department of AGRARIA, Località Feo di Vito, 89122 Reggio Calabria, Italy.

E-mail: bruno.bernardi@unirc.it
}

Key words: Mechanical grading, PGI Tropea red onion, productivity, working capacity.

Authors have contributed equally to present work.

(C) Copyright B. Bernardi et al., 2013

Licensee PAGEPress, Italy

Journal of Agricultural Engineering 2013; XLIV(s2):e63

doi:10.4081/jae.2013.s2.e63

This article is distributed under the terms of the Creative Commons Attribution Noncommercial License (by-nc 3.0) which permits any noncommercial use, distribution, and reproduction in any medium, provided the original author(s) and source are credited.

\section{Introduction}

Nowadays, the modern agri-food chain requires an increasingly advanced planning that aims to improve and increment productions qualitative level (Cavalli et al., 2011). The added value associated to the "territory" of some products, such as the Red Onion of Tropea (Calabria- Southern Italy), can therefore assume a great importance and contribute considerably to rural development and agricultural diversification (Gulisano et al., 2000). In addition, organoleptic features provided by this product that has PGI label (EC, 2008), should be connected as well to the quality of services that accompanies its processing and marketing (Fafani et al., 1997). Such scenario should lead the agri-food industries to strengthen their productive systems and modify the current production, distribution and marketing settings (Fabbris, 1989), that are still not suitable to supply markets of typical products. Consumers' expectations and consequently global markets require standardized and homogeneous products with quality and size tolerances tending to zero. Moreover, productions should be characterized by a continuity of supply that have a strict compliance with delivery time, as well as bargaining forms for consistent provisions programmable for the medium and long terms. Regardless intrinsic qualitative features that provides the red onion of Tropea (nutritional, organoleptic and sanitary ones), the optimization of some post-harvest operations such as those related to its grading can certainly contribute to make faster and less burdensome this processing phase. Diverse types of machines and plants are available to carry out this operation (Amirante et al., 1988; Baraldi et al., 1998; Peri, 1986; Oberti et al., 2001; Mignani, 2001). But, the main problem concerns the removal of the external layers of the "protection coat", which make difficult to employ optical or electronic graders in a satisfactory way. In this context, the present experimental study has been achieved in order to analyze one of the most important post-harvest processing phases, which is grading, and assess work efficiency of Tropea red onion mechanical graders, considering productive outputs and highlighting critic points and optimization possibilities of the employed machines.

\section{Materials and methods}

Experimental trials have been carried out in two firms, indicated in this paper as A and B, among the most advanced technologically within Tropea red onion production area. Processing chain in these firms is almost standardized. Grading, that is products sorting according to their size (Menesatti, 2000; Ortiz-Cañavate et al., 2002), begins with manual sorting of the bulbs and the subsequent "tailing" that consists in the removal of the dried leaves, also known as tail, at about one centimeter from the bulb. The process then, continues by placing the onions in the graders, to which follow weighing and packing operations. Grading in firm A is achieved by mean of two different machines: the first one (Figure 1) presents three processing lines, 
composed of opposite and divergent pairs of counter-rotating endless belts. The bulbs move on between the rollers, whose difference creates a growing gap through which the onions fall according to their size, inside of hoppers, from where they are then sent in apposite bins.

The second machine, however, is a continuous cycle rollers type composed of a sequence of forced rotation bobbins pairs that create a gap equal to onions size between two consecutive pairs, thanks to the inclination they undergo (Figure 2).

Bobbins system ensure the continuous and independent adjustment of grading size in each separate section, enclosing so, the largest dimensional range, while the forced rotation of the bobbins ensure the ideal positioning that enable grading of each single product.

Firm B, however, employs a grade screen sizer (Figure 3): a conveyer belt carries the products to the sorting zone, where metallic cylinders with holes of diverse dimensions are set up. While vibrating, they grade the onions according to their size, and then, unload the processed products in the appropriate bins.

The conducted trials, aimed to determine grading operations accuracy of the considered processing lines. A series of bulbs with different size have been selected to verify the influence of the product size on the precision. The bulbs have been numerated, then, the maximum diameter of the transversal section of each one has been measured manually with a Vernier caliper. Such diameter is commonly known as maximum "equatorial diameter", although the largest transversal section of the bulb is rarely encountered in the median zone. Subsequently, onions underwent a normal grading cycle in order to assess machines working efficiency. Moreover, working time as well as graders performances have been analyzed, according to C.I.O.S.T.A. ranking requirements (Bolli et al., 1987), considering machines starting as the beginning of trials, the final point, however, corresponded to the end of products unload.

\section{Results and discussion}

\section{Firm A}

As reported previously, in this firm, there are two onions graders, the first one with inclined belts, and the second one with rollers, having the same four dimensional classes or grading issues (30-50; 51-70; 71-90; $>90$ ). Graphic 1 sums up percentages of onions that fell in the different dimensional classes, in both graders of firm A. It provides a first indication about the size of processed onions in this firm, which is over $70 \mathrm{~mm}$ for almost all samples.
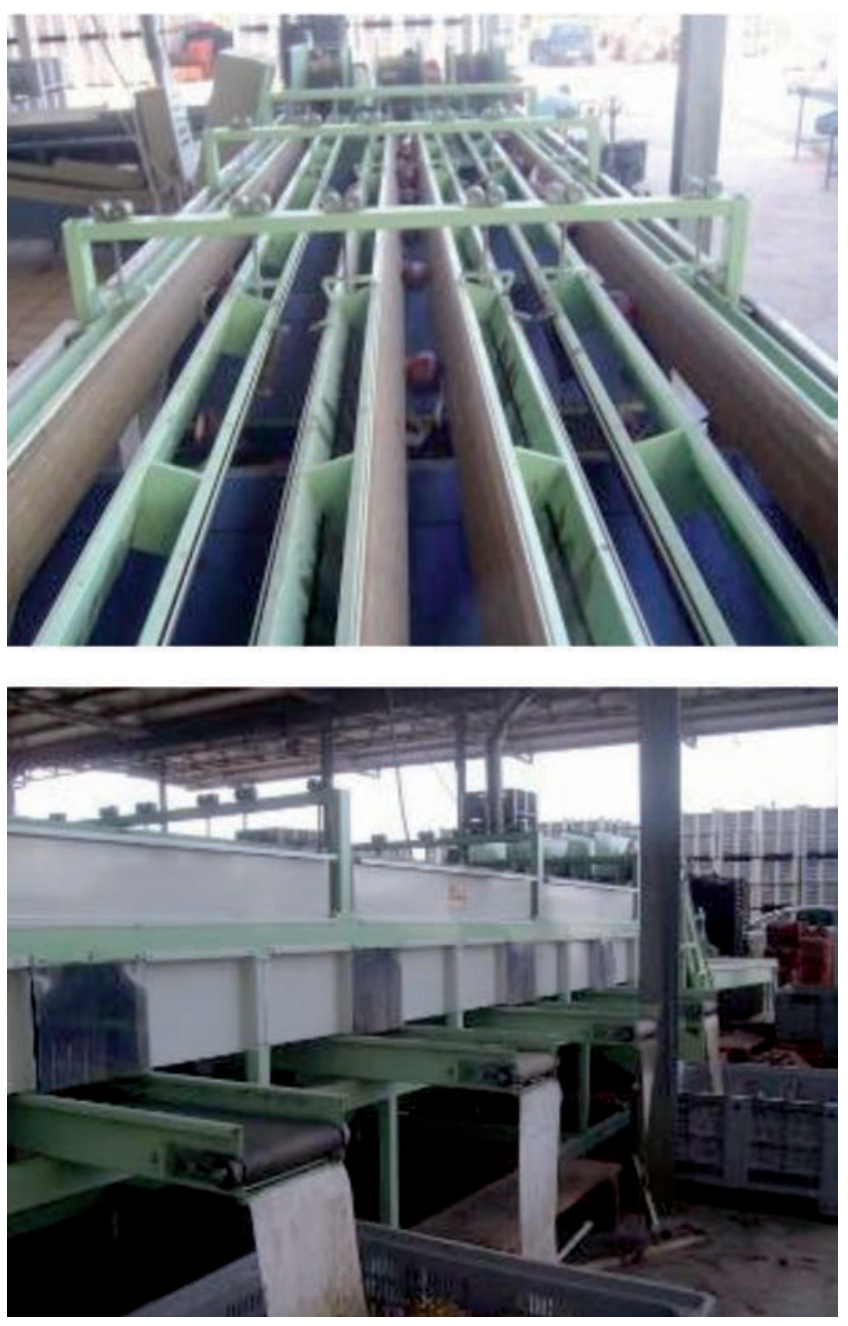

Figure 1. Onion grader with inclined belts.
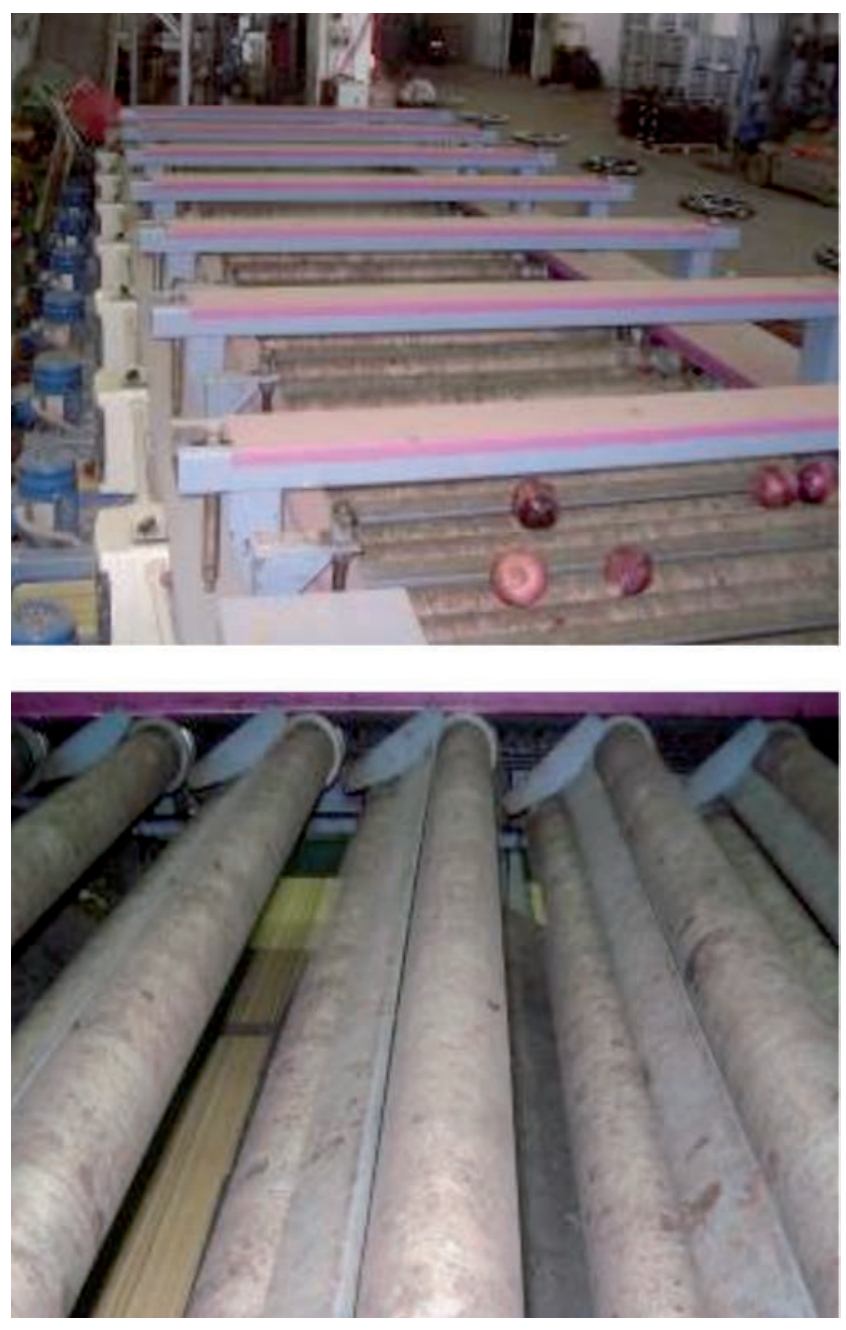

Figure 2. Onion grader with rollers. 
Graphic 2 reports, however, the average size of graded onions samples, as well as the respective standard errors. It can be observed that onions appertaining to lower dimensional classes are hardly identified by both graders, while, onions that belong to the most frequent commercial classes, that is, equal or more than $70 \mathrm{~mm}$ are graded with more accuracy independently from grader type.

According to Graphic 3, the highest graders efficiency is reached when values obtained from the ratio between not correctly graded onions and total graded one for each dimensional class, are closed to zero. Explaining so, the capability of the grader to recognize the highest number of onions appertaining to a specific dimensional class. In general, a high accuracy is recorded for both graders, even if the most reliable one was the grader with inclined belts. It has to be noted that for extreme calibres, there was some difficulties to recognize the correct issue, however, the highest accuracy was obtained for the dimensional class of 71-90 mm.

Working time measurements achieved during trials for both graders of firm A are shown in Table 1. Reference timing unit corresponded to the amount of minutes required to grade one hundred kilograms of the product. Operative time could be calculated as well.

These data, show that the lowest operative working time (T0), equal to $3.20 \mathrm{~min} / 100 \mathrm{~kg}$, was recorded for onion grader with inclined belts,
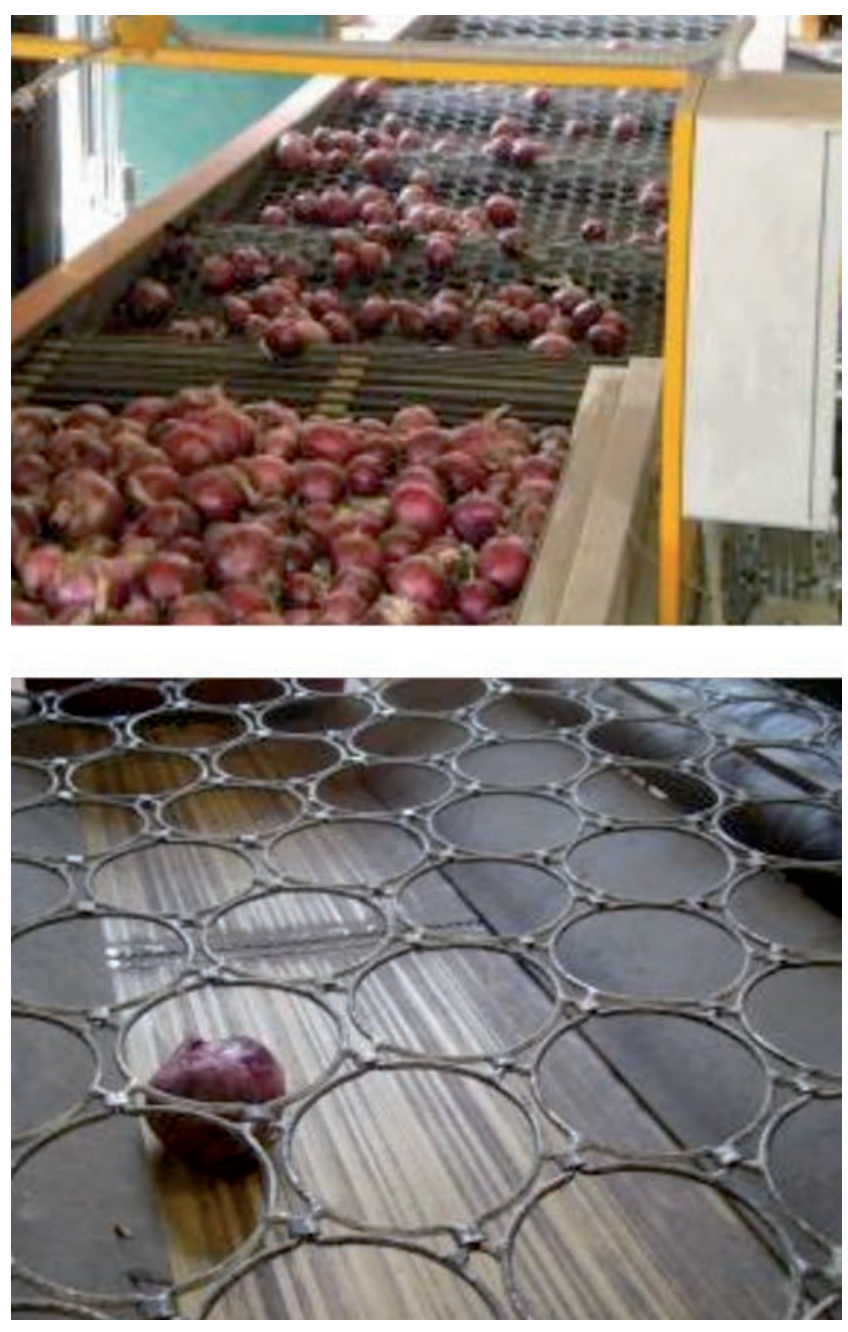

Figure 3. Onions grade screen sizer (firm B).

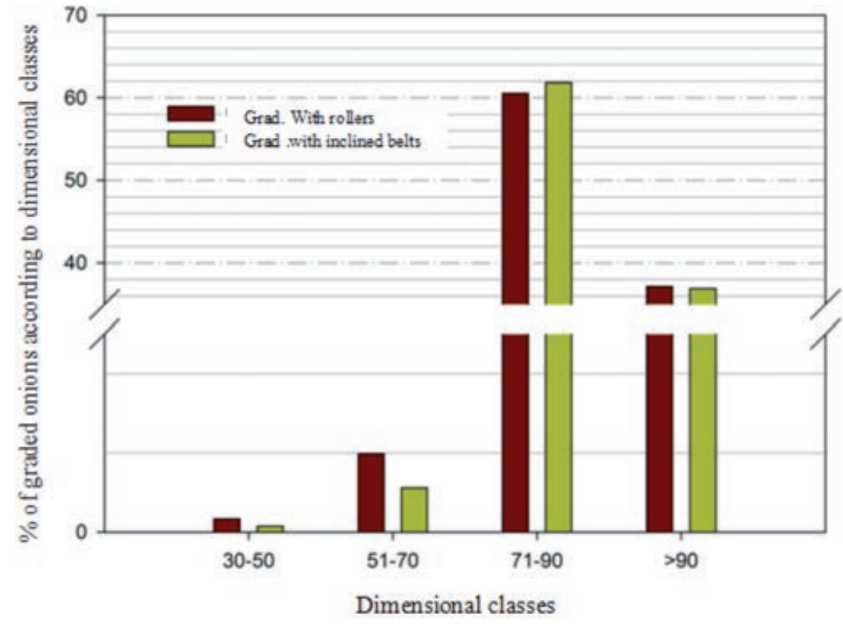

Graphic 1. Percentage of graded onions according to the different dimensional classes in firm $\mathrm{A}$.

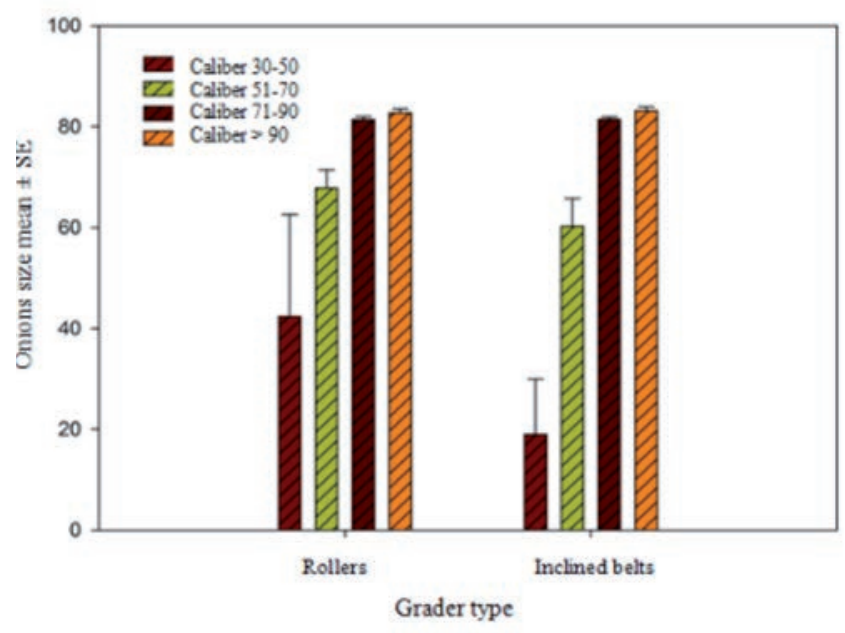

Graphic 2. Onions size mean \pm standard error for each dimensional class according to grader type.

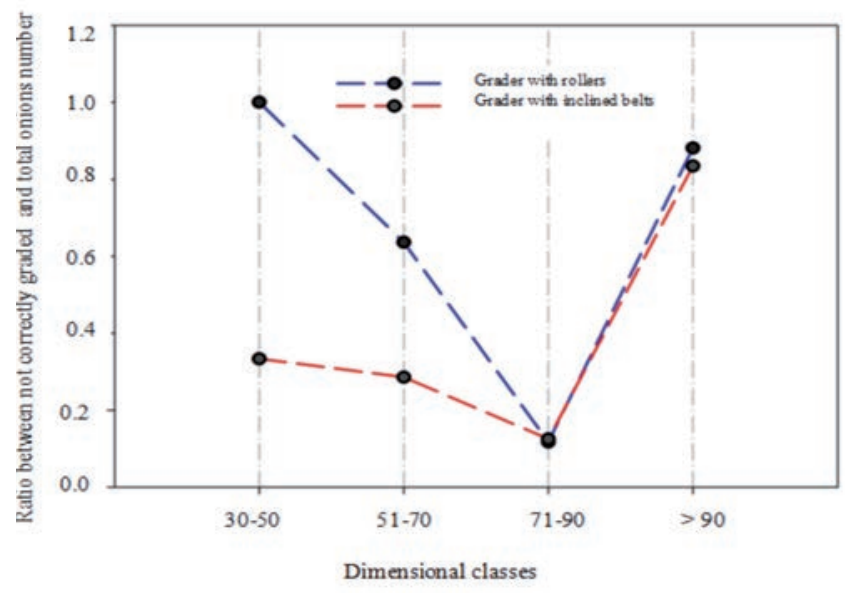

Graphic 3. Graders working efficiency in firm A. 
however, the grader with rollers presented almost the double value $(5.43 \mathrm{~min} / 100 \mathrm{~kg})$. Idle time has not been registered, showing so the good functioning of both graders and the ability of laborers charged of processing. From working time values, it was possible to obtain working capacity and productivity for the analyzed graders, whose values are reported in Table 2, taking into account the employment of three processing units for each machine. Operative working capacity of the grader with inclined belts according to T0 had a value of $1,800 \mathrm{~kg} / \mathrm{h}$ while operative working productivity (P0) had a value of 600 kilograms per hour per operator (kg/hop). For the grader with rollers, these parameters assumed respectively the values of $1,040 \mathrm{~kg} / \mathrm{h}$ for working capacity and $349 \mathrm{~kg} / \mathrm{hop}$ for operative working. Therefore, it clearly emerges that the grader with inclined belts is better than the other one in terms of both working capacity and productivity.

\section{Firm B}

In this firm, there are six dimensional classes for onions grading, divided as follows: 25/40, 40/50, 50/60, 60/70, 70/80, 80/100. Graphics 4 and 5 indicate that the greatest number of graded onions appertained to dimensional classes having the caliber between 60 and $80 \mathrm{~mm}$. Furthermore, product size differences between the two firms can be observed, processed onions in firm B being smaller.

Graphic 6 reports however the onions grade screen sizer efficiency. A high accuracy is observed even in this case. But differently from firm A, here, there are some difficulties for the recognition of the correct caliber of big size onions, however, the highest grading precision is obtained for the smallest dimensional class $25-50 \mathrm{~mm}$.

Table 3 show the recorded effective and operative working times during onions grading by mean of the screen sizer.

These data, reveal that operative working time (T0) of the last grader, equal to $6.25 \mathrm{~min} / 100 \mathrm{~kg}$, is the highest one. Indeed, although still technologically valid, it represents a less recent model than the previous two graders. However, There were not idle times, highlighting once more the good functioning of the machine and the ability of laborers that accompany graders. From time values, it was therefore possible to obtain work capacity and productivity of the grade screen sizer, whose values are reported in Table 4, considering the employment of three working units. Operative working capacity (according to T0) had a value of $935 \mathrm{~kg} / \mathrm{h}$ while, operative working productivity (P0) was equal to $311 \mathrm{~kg} / \mathrm{hop}$.

\section{Conclusions}

The conducted analysis on onions post-harvest operations, highlighted that the employed graders are able to ensure a high working capacity, maintaining a notable accuracy during grading and weighing operations. Such precision allows to reduce man power employment and make faster processing chain, engendering machines annual utilization increase and processing costs saving. It is to be noticed that the employment of two processing lines in firm A is excessive, given that the grader with inclined belts is enough for achieving rapidly and accurately this operation. Obtained data support therefore the managerial decision to substitute the grader with rollers by more graders with inclined belts. First models of optical grading machines start to be employed, however, these one do not represent an easy solution for onion grading, because external protective coats could highly interfere

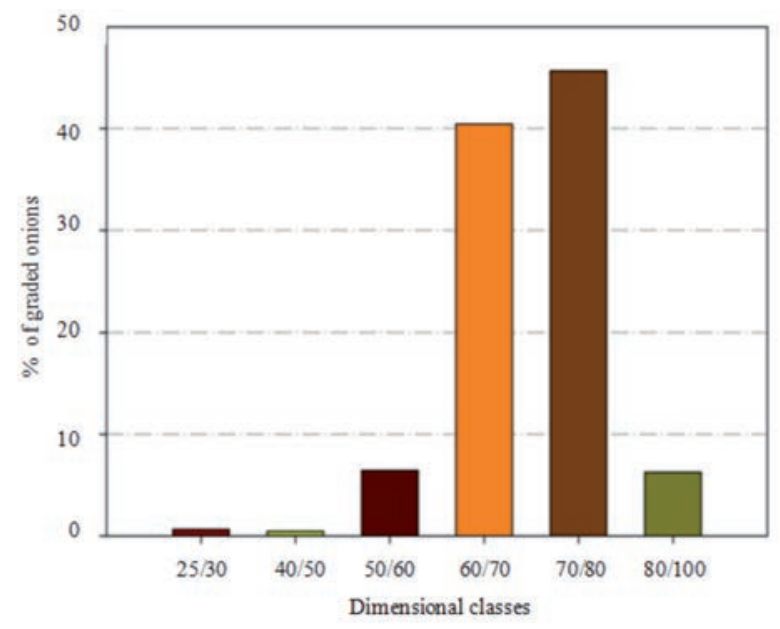

Graphic 4. Percentage of graded onions according to the different dimensional classes in firm $B$.

Table 1. Graders average working time in firm A.

\begin{tabular}{|c|c|c|c|c|c|c|c|}
\hline \multirow[t]{2}{*}{ Grader type } & \multirow[t]{2}{*}{$\begin{array}{c}\text { TE } \\
{[\mathrm{min} / 100 \mathrm{~kg}]}\end{array}$} & \multicolumn{3}{|c|}{$\begin{array}{c}\text { TA } \\
{[\mathrm{min} / 100 \mathrm{~kg}]}\end{array}$} & \multirow[t]{2}{*}{$\begin{array}{c}\text { T0 } \\
{[\mathrm{min} / 100 \mathrm{~kg}]}\end{array}$} & \multicolumn{2}{|c|}{$\begin{array}{c}\text { TM } \\
{[\mathrm{min} / 100 \mathrm{~kg}]}\end{array}$} \\
\hline & & TAS & TAC & TOTAL & & TME & TMI \\
\hline Inclined belts & 3.00 & 0.20 & - & 0.20 & 3.20 & - & - \\
\hline Rollers & 5.13 & 0.30 & - & 0.30 & 5.43 & - & - \\
\hline
\end{tabular}

TE: Effective working time; TA: Accessory time; TAS: Accessory time for unloading; TAC: Accessory time for handling; TO: Operative working time; TME: Evitable idle time; TMI: Inevitable idle time.

Table 2. Working capacity and productivity of the employed graders in firm A.

\begin{tabular}{|c|c|c|c|c|c|}
\hline \multirow[t]{3}{*}{ Grader } & \multicolumn{4}{|c|}{ Working capacity } & \multirow{3}{*}{$\begin{array}{c}\text { Working productivity } \\
\text { Referred to TO } \\
\text { [100 kg /hop] }\end{array}$} \\
\hline & \multicolumn{2}{|c|}{ Referred to TE } & \multicolumn{2}{|c|}{ Referred to TO } & \\
\hline & [ $\mathrm{min} / 100 \mathrm{~kg}]$ & {$[100 \mathrm{~kg} / \mathrm{h}]$} & {$[\mathrm{min} / 100 \mathrm{~kg}$} & [100 kg /h] & \\
\hline Inclined belt & 3 & 20 & 3.20 & 18 & 6 \\
\hline Rollers & 5.13 & 11.50 & 5.43 & 10.4 & 3.49 \\
\hline
\end{tabular}




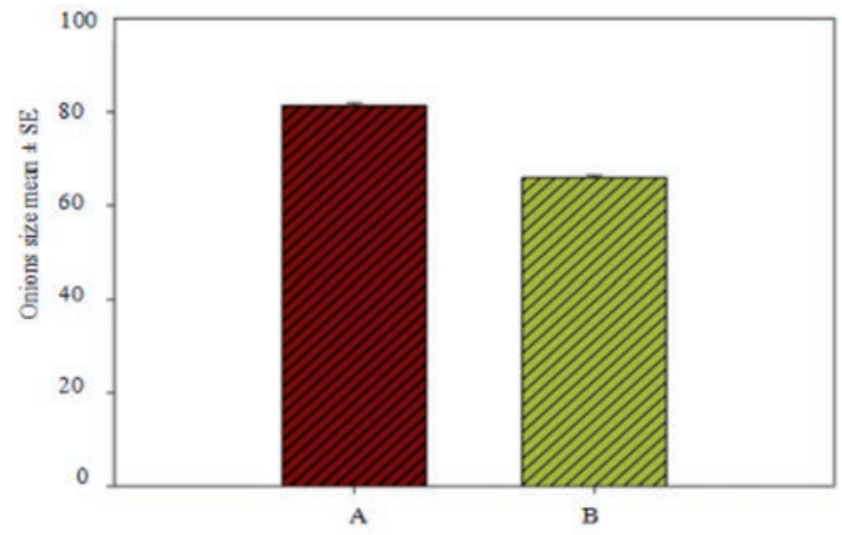

Graphic 5. Dimensional differences of the processed onions between firms $A$ and $B$.

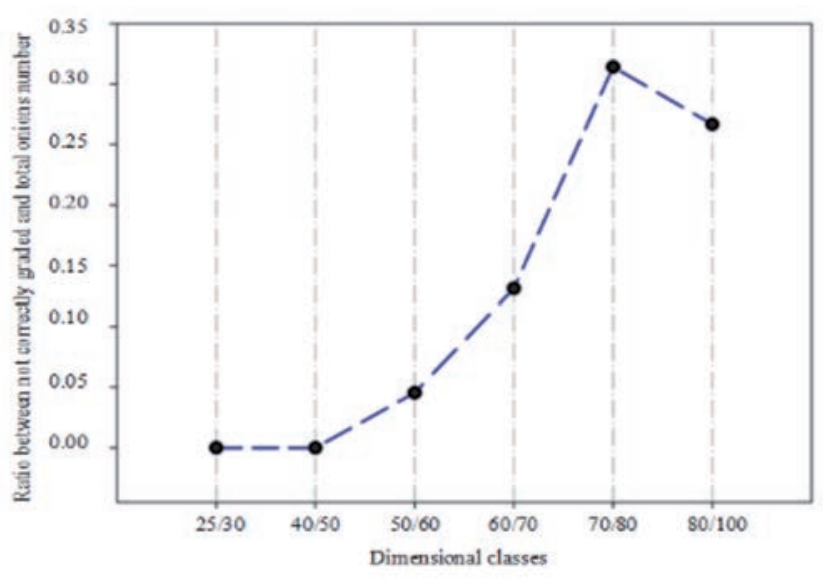

Graphic 6. Working efficiency of the onions grade screen sizer used in form $B$.

Table 3. Average working times of the onions grade screen sizer used in firm B.

\begin{tabular}{|c|c|c|c|c|c|c|c|}
\hline \multirow[t]{2}{*}{ Grader } & \multirow[t]{2}{*}{$\begin{array}{c}\text { TE } \\
{[\mathrm{min} / 100 \mathrm{~kg}]}\end{array}$} & \multicolumn{3}{|c|}{$\begin{array}{c}\text { TA } \\
{[\mathrm{min} / 100 \mathrm{~kg}]}\end{array}$} & \multirow[t]{2}{*}{$\begin{array}{c}\mathrm{TO} \\
{[\mathrm{min} / 100 \mathrm{~kg}]}\end{array}$} & \multicolumn{2}{|c|}{$\begin{array}{c}\text { TM } \\
{[\mathrm{min} / 100 \mathrm{~kg}]}\end{array}$} \\
\hline & & TAS & TAC & TOTAL & & TME & TMI \\
\hline Screen sizer & 5.35 & 0.25 & 0.25 & 0.50 & 6.25 & - & - \\
\hline
\end{tabular}

Table 4. Working capacity and productivity of the onions grade screen sizer used in firm B.

\begin{tabular}{|c|c|c|c|c|c|}
\hline \multirow[t]{3}{*}{ Grader } & \multicolumn{4}{|c|}{ Working capacity } & \multirow{3}{*}{$\begin{array}{c}\text { Working productivity } \\
\text { Referred to T0 } \\
\text { [100 kg /hop] }\end{array}$} \\
\hline & \multicolumn{2}{|c|}{ Referred to TE } & \multicolumn{2}{|c|}{ Referred to TO } & \\
\hline & [min/100 kg] & [100 kg /h] & {$[\mathrm{min} / 100 \mathrm{~kg}]$} & {$[100 \mathrm{~kg} / \mathrm{h}]$} & \\
\hline Screen sizer & 5.35 & 10.74 & 6.25 & 9.35 & 3.11 \\
\hline
\end{tabular}

reception and transmission sensors. For these reasons, optical systems do not respect perfectly accuracy threshold declared by their constructors, although they are among the most advanced and accurate systems. Competition capability recovery passes through the valorization of typical products, accompanied by the rigorous and complete application of high quality standards, excellent presentations and various assortments. The introduction of graders such as those analyzed in this study, can certainly contribute for the accomplishment of the above cited objectives, since they present suitable features for post-harvest processes optimization.

\section{Acknowledgement}

This work is part of the ongoing project Dolce Rossa supported by the APQ "Scientific Research and Technological Innovation" (Az. 2 and Az. 3) financed by Calabria Region-Department of Research, European Community, Italian Ministry of Economic Development (MISE) and Italian Ministry of Research Science and Technology (MIUR).

\section{References}

Amirante P., Cappiello M., Di Renzo G.C. 1988. Meccanizzazione delle operazioni post-raccolta come cerniera tra produzione e commercializzazione. IV Convegno Nazionale di Genio Rurale, Porto Conte - Alghero, Maggio.

Baraldi E., Ragni L. 1998. La moderna tecnologia per la meccanizzazione dei processi post-raccolta. L'Informatore Agrario. 28: 25-48.

Bolli P., Scotton M. 1987. Lineamenti di tecnica della meccanizzazione agricola. 1a Edizione. Edagricole, Bologna, Italia. $221 \mathrm{pp.}$

Cavalli R., Monarca D. 2011. Lo stato e le prospettive della ricerca nel settore AGR/09. Convegno di Medio Termine dell'Associazione Italiana di Ingegneria Agraria. Belgirate, 22-24 settembre 2011.

EC, 2008. Regolamento (CE) N. 284/2008 della commissione del 27 marzo 2008 recante iscrizione di alcune denominazioni nel registro delle denominazioni d'origine protette e delle indicazioni geografiche protette.

Fabbris L. 1989. Consumatore e mercato. Sperling \& Kupfler Editori.

Fafani R., Sullace S. 1997. I consumi alimentari in Italia ed in Europa, 
cambiamenti strutturali, convergenza e differenziazione. La questione agraria. n. 67.

Gulisano G., Privitera D. 2000. Strategies of marketing of a traditional vegetable product: the red onion in Tropea. Proc. XIVth Intrnational Symposium on Horticultural Economics, 12-15 September, Acta Horticulturae, ISHS.

Menesatti P. 2000. Misura strumentale della qualità in ortofrutticoltura. Italus Hortus. 2: 12-19.

Mignani I. 2001. Gli aspetti fisiologici delle tecnologie non distruttive. Atti del convegno: La qualità dei prodotti ortofrutticoli: stato dell'arte sull'uso delle tecnologie non distruttive, MACFRUT, Cesena, maggio.
Oberti R., Guidetti R., Naldi E. 2001. Progettazione di un sistema di calibrazione ottico a basso costo per prodotti ortofrutticoli. Congresso A.I.I.A., Vieste (FG), settembre.

Ortiz-Cañavate J., Moreda G., Homer I., Morabito S., Ruiz-Altisent M. 2002. Fruit size determination by a new optical sensor. International Conference on Agricultural Engineering (AgEng), Budapest, Hungary.

Peri C. 1986. Nuove frontiere della tecnologia alimentare: le mild tecnologies", progetto finalizzato IPRA del CNR. Atti del convegno "Nuove frontiere della tecnologia alimentare: le mild tecnologies", Roma, novembre. 